\title{
Lower End of Maritime Operations: European Union Migrant and Border Control Operations in the Central Mediterranean
}

\author{
John Sherwood
}

In 2015, the European Union (EU) confronted a seaborne migration of unprecedented proportions. Over 1.8 million people fled Africa and the Middle East for Europe-a number over six times the number of illegal border crossings (both on land and sea) in $2014 .{ }^{1}$ The crisis was caused by push factors such as war and poverty as well as pull factors like German Chancellor Angela Merkel's decision in 2015 to open Germany's borders to refugees fleeing war in Syria, Afghanistan and Iraq.

The EU responded by launching several coastguard and naval operations in the Mediterranean. Initially, these migrant operations focused mainly on saving lives at sea but over time evolved into multifaceted efforts designed to combat human trafficking, secure Europe's borders, stop the smuggling of arms and oil, and provide enhanced maritime security for the union. While criticised by the right for "providing a water taxi for illegal immigrants" and by the left for their strategic partnerships with the coastguards of Libya and Turkey (countries with poor human rights records), the operations succeeded in stemming the tide of migration to Europe, and more importantly, strengthened nascent EU security structures, such as Frontex (the European Border and Coast Guard Agency) and the EU Common Security and Defence Policy (CSDP). They have also created a greater sense of European solidarity amongst the many sea services personnel who participated in these operations.

For policymakers in the EU, these operations reveal that coastguards and navies, with cooperation from international partners, can save lives and secure borders even in the direst migration crises. They also underscore the immense challenges of migration operations. On a tactical level, these include the logistical challenges of rescuing and transporting large numbers of migrants in naval vessels; coordination between different states and non-governmental actors; and performing a mission with a multifaceted mandate. On a strategic level, the operations have had to contend with changing mandates and immigration policies; harsh critics in the me-

1 Frontex, General Report, 2014, 3. 
dia and in the political sphere; legal and human rights concerns; prickly interactions with foreign militaries and governments; conflicts between the operation's values and the reality of the situation at the deck-plate level; and connecting maritime strategy with broader migration policy initiatives on the shore. Migration operations represent some of the most complex low-end missions a navy will ever confront.

The focus of this paper will be on the crisis in the Central Mediterranean, and operations Triton and Sophia in particular. While the Aegean experienced a greater surge of migration in 2015, the Central Mediterranean route off the coast of Libya was the first and only area to be patrolled by an EU naval force. As such, it is more illustrative of both the various roles naval units can play in migratory operations and some of the pitfalls.

\section{Operation Triton}

The origins of the migration crisis in the Central Mediterranean can be traced to the 2011 civil war in Libya. That war created an ungoverned coastline that migrants could use as a launch pad to Europe via the islands of Lampedusa and Malta. By August 2013, the number of migrants reaching Italy and its islands by sea had nearly doubled from a former high in 2011 of 60,000 to over 100,000. ${ }^{2}$ In October 2013, two shipwrecks resulted in the deaths of over 500 migrants. ${ }^{3}$ These tragedies spurred the Italian government to launch Operation Mare Nostrum, a maritime operation designed to "safeguard human life at sea and bring justice to human traffickers and migrant smugglers". Mare Nostrum, a joint operation involving the Italian Navy, Coast Guard and other agencies, saved over 140,000 lives in less than a year, but it was more than a single member state could handle financially. ${ }^{4}$ On 9 October 2014, Italy announced that due to high costs

2 Sylvia Poggioli, "Italy Undertakes Lonely, Expensive Mission to Aid Migrants at Sea,” NPR, 24 August 2014, https://www.npr.org/sections/parallels/2014/08/12/339 881610/italy-undertakes-lonely-expensive-mission-to-aid-migrants-at-sea, accessed 7 April 2020.

3 Glenda Garelli et al., "Shifting Bordering and Rescuing Practices in the Central Mediterranean Sea, October 2013-October 2015," Antipode, vol. 50, No. 3 2018, 813-821.

4 UNHCR, "So Close yet So Far from Safety: Refugees and Migrants Risking Their Lives at Sea to Reach Europe,” 2014, https://www.unhcr.org/protection/migration/ 542c07e39/close-far-safety-2.html, accessed 9 February 2021. 
(more than $€ 9$ million a month), it was ending the operation. ${ }^{5}$ Critics of the operation claimed Mare Nostrum had encouraged migration, but officers involved dismissed this notion. "The boats will try and make the passage anyway," explained Italian Rear Admiral Michele Saponaro, "The naval operation ensures that migrants are identified and lives are saved." 6 Throughout my research, numerous European coastguard and naval officers made the same argument: naval and coastguard presence in the migration zones promotes orderly migration and saves lives.

The crisis did not end with the conclusion of operation Mare Nostrum. By late 2014, significant numbers of migrants continued to attempt to reach Europe by sea. During 2014, EU authorities detected 280,000 crossings, more than twice the previous record set in 2013. The most heavily transited corridor in 2014 was the Central Mediterranean with some 170,000 migrants detected by Frontex, the EU border agency. ${ }^{7}$ To assist Italy and Malta in managing these flows, Frontex launched Joint Operation Triton in November 2014. Triton employed coastguard assets detailed by member states for border surveillance and border control. In contrast to Mare Nostrum, search and rescue operations (SAR) were not part of the Frontex mandate. However, several maritime laws obligated Frontex vessels to engage in rescues. These included the 1974 International Convention for the Safety of Life at Sea (SOLAS), the 1979 International Convention on Maritime Search and Rescue (SAR), and Article 98 of the UN Convention on the Law of the Sea (UNCLOS). Under these laws, Triton vessels had to be ready to perform rescues if ordered to do so by the Italian Coast Guard's Maritime Rescue Coordination Centre (MRCC) in Rome. ${ }^{8}$ Triton's area of operation (AOR) covered the territorial waters of Italy and Malta, as well as parts of the search and rescue (SAR) zones of both states. Although Triton provided additional SAR capacity for Italy, it did not offer the same range of coverage as Mare Nostrum in international waters, which had deployed warships right up to the 12 nautical maritime borders of Libya. A significant sea gap existed between Libyan territorial waters and the beginning of the Triton SAR zone. ${ }^{9}$

5 Gian Lorenzo Zichi, "European Fleet to address the Migration Challenge in the Mediterranean? The EUNAVFOR MED/Sophia between Lights and Shadows," Athens Journal of Mediterranean Studies, Volume 4, Issue 2, 137-156.

6 Poggioli.

7 Frontex, Annual Activity Report (AAR) 2014, 13 May 2015, 14.

8 Guardia Costiera is part of the Italian Navy but under the control of the Ministry of Infrastructure and Transport.

9 Frontex, AAR 2014, 14-15. 
During its first two months of operation, over 1,000 officers, up to 9 offshore patrol vessels (OPVs) and 5 aircraft participated in Triton. These forces rescued over 14,000 people and arrested 57 suspected human traffickers. ${ }^{10}$ Despite these efforts, migrant crossings continued unabated. In April 2015, five migrant boats carrying nearly 2,000 immigrants sank in the Central Mediterranean outside the Frontex AOR, killing more than 1,200 people. ${ }^{11}$ One sinking near Lampedusa killed over 800 people. ${ }^{12}$ These tragedies took place just before a European Council (EC) meeting on 23 April and spurred it to immediate action. The EC extended the Triton SAR zone 138 miles south of Sicily and directed the European External Action Service (EEAS) to prepare for a CSDP operation to undertake a mission to "disrupt the business model of human trafficking". Ships and aircraft from the new operation were to patrol much of the sea gap between the territorial waters of Libya and the southern and eastern edge of the Triton SAR zone.

As a stopgap, several member states (including Belgium, Germany, Italy, Ireland and the UK) sent naval vessels to the Central Mediterranean to augment Triton until the new EU Naval Force Mediterranean (EUNAVFOR MED) could be launched. These larger vessels could accommodate more migrants and possessed technology not generally found on cutters: thermal cameras, cell phone interception equipment, and linked data from other ships and shore facilities. As the commander of the Belgian naval ship Godetia explained, "I had more information than Frontex headquarters because as a Navy ship I was getting linked data from NATO." 13

The launch of EUNAVFOR MED did not end the efforts of Frontex in the same region. During 2015, Triton units were to rescue 38,000 people and over 23,000 in 2016. From 2015-2018, Frontex deployed 523 officers and 9 patrol vessels from $26 \mathrm{EU}$ member states in the Triton AOR. ${ }^{14}$

10 Frontex, AAR 2014, 17-18; House of Lords, European Union Committee, “Operation Sophia, the EU's naval mission in the Mediterranean: an impossible challenge." $14^{\text {th }}$ Report of Session 2015-16, 13 May 2016.

11 Garelli, 813-821.

12 Federica Mogherini, "Congratulations to the EU Military Staff on your $15^{\text {th }}$ Anniversary — 2001 / 2016," IMPETUS: Magazine Of The EU Military Staff, European External Action Service (EEAS), Brussels, Spring/Summer 2016 Issue \#21, 2-4.

13 CDR Philippe De Cock BN, interview with John Sherwood, 17 October 2018, telephone.

14 Council of the European Union, EU Operations in the Mediterranean Sea Fact Sheet, 4 October 2016; Eugenio Cusumano, "Migrant Rescue as Organized Hypocrisy: EU Maritime Missions Offshore Libya between Humanitarians and 


\section{Operation Sophia}

Journalists often portray Operation Sophia as a "knee-jerk" reaction by the EC to the April 2015 Lampedusa tragedy. While it certainly motivated the council to act, the concept of a CSDP maritime operation focused on migration issues had deep roots stretching back to the CSDP tasks established by the Lisbon Treaty and Europe's place in the world as envisioned in the Maastricht Treaty. In 2014, the EEAS Maritime Security Strategy (MSS) and Action Plan identified cross-border "trafficking of human beings and smuggling of migrants, organized criminal networks facilitating illegal migration, [and] trafficking of arms and narcotics, smuggling of goods and contraband" as one of the four most significant maritime threats to the union. $^{15}$

Fundamental to CSDP planning for migration operations in 2015 was the principle espoused by the MSS that EU maritime missions would be based upon four guiding principles: "a cross-sectoral approach, functional integrity, respect for rules and principles, and maritime multilateralism". ${ }^{16}$ For Sophia, this would mean an operation that adhered to EU and international laws and norms; one that was integrated with other operations (both on land and sea) and included a variety of nation state participants and organisations; and one that took a multifaceted, full spectrum approach to the problem at hand. ${ }^{17}$

With that said, the CSDP was an organ of the EC and, by extension, the 28 member states of the European Union. In 2015, there was no clear-cut consensus amongst member states regarding how the union should handle the migration crisis in the Mediterranean. In Atalanta (the first CSDP maritime operation) the mission had been straightforward: protect ships transiting the Horn of Africa from pirates and, if possible, apprehend and prosecute pirates. Merchant ships were the mission's centre of gravity. For the migration crisis, the centre of gravity was less clear. Was it saving lives and preventing drownings at sea? Protecting Europe's borders and creating en-

Border Control,” Sage Journals, 6 June 2018, https://journals.sagepub.com/doi/full /10.1177/0010836718780175, accessed 20 May 2010.

15 Council of the European Union, European Union Maritime Security Strategy (EUMS), 24 June 2014.

16 High Representative of the Union for Foreign Affairs and Security Policy, European Commission, Second report on the implementation of the EU Maritime Security Strategy Action Plan, 14 June 2017, 5.

17 EUMS 2014. 
hanced awareness and security in the maritime domain? Or combatting migrant smuggling and human trafficking?

Christophe Goussot, the EEAS's CSDP coordinator for Libya and the Lead Strategic Planner for Operation Sophia, was involved in many of the early debates about Sophia and its mission. He explained to me in 2019 that there were three distinct groups of member states:

1. The framework country, Italy, which was focused mainly on migration [i.e. how to control it].

2. States solely focused on search and rescue and saving lives. The leading proponent of this approach was Germany.

3. States concerned with the broader strategic context: stability in the central Mediterranean. Migrant smuggling is a symptom of a broader problem. This group was led by France and the United Kingdom. ${ }^{18}$

The naval mission that resulted from these discussions incorporated all three of these concerns. On 15 May 2015, the EC announced that it would be initiating a new CSDP mission to "conduct a military crisis management operation contributing to the disruption of the business model of human smuggling and trafficking networks in the Southern Central Mediterranean (EUNAVFOR MED) .... in accordance with applicable international law, including UNCLOS and any UN Security Council Resolution". ${ }^{19}$

This goal would be achieved in three phases. The first phase would consist of monitoring the migration networks in the Central Mediterranean and "patrolling on the high seas in accordance with international law". In practice, Phase 1 would involve extensive SAR type work in accordance with UNCLOS, SOLAS and the 1979 SAR Convention. ${ }^{20}$ As Goussot explained, "it is not a SAR operation. It was designed to disrupt the business model of human trafficking. But, of course, because of the nature of the crisis and EU member state obligations under SOLAS and UNCLOS, the operation initially involved quite a lot of search and rescues (SOLAS incidents)". ${ }^{21}$

To disrupt human trafficking, Phase 2A stated that forces of EUNAVFOR MED would begin conducting "Boarding, search, seizure

18 Christophe Goussot, interview with author, 20 June 2019, telephone.

19 Official Journal of the European Union, COUNCIL DECISION (CFSP) 2015/778 of 18 May 2015 on a European Union military operation in the Southern Central Mediterranean (EUNAVFOR MED), 19 May 2015.

20 COUNCIL DECISION (CFSP) 2015/778 of 18 May 2015.

21 Goussot interview. 
and diversion on the high seas of vessels suspected of being used for human smuggling or trafficking, under the conditions provided for by applicable international law". ${ }^{22}$ Once an appropriate UN Security Council Resolution (UNSCR) had been passed and the Libyan government provided its consent, EUNAVFOR MED warships, in Phase 2B, would begin interdicting vessels suspected of "being used for human smuggling or trafficking" in Libyan territorial waters. Under Phase 3, as authorised by a new UNSCR as well as consent by Libya, EUNAVFOR MED would "take all necessary measures against a vessel and related assets, including through disposing of them or rendering them inoperable, which are suspected of being used for human smuggling or trafficking, in the territory of that State, under the conditions set out in that Resolution or consent". ${ }^{23}$ Phases $2 \mathrm{~A}, 2 \mathrm{~B}$ and 3 were meant to combat human trafficking and thereby reduce illegal immigration and improve overall maritime security in the regionthus addressing the concerns of Italy, France and the UK. The operation officially commenced at sea on 22 June 2015 . Twenty-six member states ultimately contributed either ships, aircraft or personnel to the operation. ${ }^{24}$

The humanitarian principle of non-refoulment, as enshrined in the Charter of Fundamental Rights of the European Union, prevented EU ships from returning migrants to Libya. Under this principle, "no one may be removed, expelled or extradited to a State where there is a serious risk that he or she would be subjected to the death penalty, torture or other inhuman or degrading treatment or punishment." 25 The Dublin Regulation stipulates that the first EU member state that a migrant reaches (either by land, sea or air) is responsible for processing that person's asylum claim. Effectively, these rules meant that most migrants intercepted by EU vessels were disembarked in Italy. That number totalled 154,000 in 2015-a figure slightly lower than the 170,000 who had arrived the previous year but still alarming to the Italian government and populace. ${ }^{26}$ Sophia forces deliv-

22 COUNCIL DECISION (CFSP) 2015/778 of 18 May 2015.

23 ibid.

24 Martin Ewence, "ANALYSIS - Enduring response: EU NAVFOR and the Mediterranean migration crisis," Jane's Navy International, 18 November 2015, 16.

25 Official Journal of the European Communities, Charter of Fundamental Rights Of The European Union, 18 December 2000.

26 International Organization for Migration (IOM), Global Migration Trends 2015 Factsheet, 19 April 2016, https://www.iom.int/news/iom-releases-global-migration -trends-2015-factsheet, accessed 16 April 2020. 
ered over 8,000 refugees to Italy; Triton, over 38,000; and the rest were rescued by NGOs, merchant vessels and the Italian security services. ${ }^{27}$

Most migrants interdicted by Sophia units ended up in "Hotspots" in Italy at Lampedusa Island, and at Trapani and Pozallo in Sicily. As originally conceived, Hotspots were meant to be temporary reception centres, not permanent camps. ${ }^{28}$ The approach called for the eventual relocation of legitimate asylum seekers to other member states. Those deemed ineligible for asylum would be returned to their home countries by Frontex. In practice, just a few states accepted migrants from Italy, and only a small number of migrants were returned to their homelands due to the non-refoulment principle.

In October 2015, Sophia forces began conducting Phase 2A operations -interrogating, searching and in some cases seizing vessels suspected of being used for human smuggling or trafficking in international waters under the legal authority of UNSCR 2240. ${ }^{29}$ During the first ten months of 2016, Sophia units captured and turned over 53 suspected smugglers to Italian authorities and disposed of 269 smuggling boats. ${ }^{30}$ These actions had no impact on unauthorised migration in the Central Mediterranean, which increased from 155,000 migrants in 2015 to over 178,000 in 2016. ${ }^{31}$

Clearly, even after the implementation of Phase 2A, Sophia was not reducing human trafficking enough to stem the flow of migration to Europe. Human traffickers knew that EU forces could not operate within the territorial waters of Libya and rarely if ever ventured further than 12 nautical miles from the coast. By the middle of 2016, these traffickers stopped using larger ocean-going vessels altogether and instead employed

27 EEAS, EUNAVFOR MED - Operation Sophia, Six Monthly Report: June $22^{\text {nd }}$ to December 31 $1^{\text {st }}$, 2015, 29 January 2016, 13; Council of the European Union, EU Operations in the Mediterranean Sea Fact Sheet, 4 October 2016.

28 Maria Margarita Mentzelopoulou and Katrien Luyten, European Parliamentary Research Service, European Parliament, Hotspots at EU External Borders State of Play, PE 623.563, June 2018.

29 See European Union Political and Security Committee, Political and Security Committee Decision (CFSP) 2016/118 of 20 January 2016 concerning the implementation by EUNAVFOR MED operation SOPHIA of United Nations Security Council Resolution 2240 (2015) (EUNAVFOR MED operation SOPHIA/1/2016), 29 January 2016.

30 EEAS, EUNAVFOR MED Op Sophia Six Monthly Report, 1 January-31 October 2016, 30 November 2016.

31 Frontex, AAR 2016, 21 June 2017, 81. 
rubber boats. Migrants, rather than traffickers, would steer the boats. ${ }^{32} \mathrm{Be}-$ cause of the flimsy nature of these craft, the EU had no legal choice but to rescue migrants once they reached international waters. According to Goussot, "the way the operation was engineered was as a rapid response to a crisis. There was a realisation in 2016 that more needed to be done for the operation to be really effective." 33

To fully succeed, Sophia needed to be able to arrest traffickers and destroy their boats in Libyan territorial waters and ashore-i.e. move to phases $2 \mathrm{~B}$ and 3. Unfortunately for the EEAS, Sophia was never able to secure permission from the Government of National Accord in Libya to enter Libyan territorial waters or from a UNSCR to provide the necessary legal authority for such operations. ${ }^{34}$ To keep France, the UK and Italy on board, the EC decided to employ the Libyan Navy Coast Guard (LNCG) as a proxy force to combat human trafficking within Libyan territorial waters. It also expanded the operation's mission beyond human trafficking. In June 2016, the Council announced that it was broadening Sophia's mandate to include (1) capacity building and training of the LNCG, and (2) contributing to information-sharing and to the implementation of the UN arms embargo in accordance with UNSCR 2292 (June 2016). ${ }^{35}$ The additional task of monitoring the oil embargo was added in July $2017 .{ }^{36}$

This LNCG partnership resulted in a dramatic decrease in migrants intercepted by EU units. At the end of 2017, the EEAS reported 118,000 unauthorised crossings in the Central Mediterranean route; ${ }^{37}$ by the end of 2018, that number had fallen to $23,487.38$ The LNCG alone intercepted 20,000 migrants in $2017 .{ }^{39}$ In 2018 , it returned 15,235 migrants to Libya. ${ }^{40}$

32 Traffickers also occasionally towed migrants to SAR areas, making outboard motors unnecessary. See CDR Sr. Grade Guy Schotte, Belgium Navy, interview with author, 25 September 2019, WhatsApp.

33 Goussot interview.

34 Op Sophia Six Monthly Report, June $22^{\text {nd }}$-December $31^{\text {st }}, 2015,19$.

35 EEAS, Strategic Review On EUNAVFOR Med Op Sophia, EUBAM Libya \& EU Liaison And Planning Cell, 26 July 2017, 30; COUNCIL DECISION (CFSP) 2016/993 of 20 June 2016 amending Decision (CFSP) 2015/778.

36 "EUNAVFOR MED Operation Sophia: mandate extended until 31 December 2018."

37 European Union Common Security and Defence Policy: Missions and Operations.

38 Frontex, Risk Analysis for 2019, 16.

39 Bathke, "When Helping Hurts."

40 No Escape from Hell, 23. Oberti, "Agreement between Italy and the Libyan coastguard." 
This partnership, however, was not without its critics. Sea rescue NGOs reported numerous abuses committed by Libyan coastguards: violations ranged from discharging weapons indiscriminately to rape and murder. Hans Witthöft, a RHIB driver with Sea-Eye in 2018, rescued women who had been raped by a Libyan coastguard unit. "They wanted to jump overboard. They had no will to live." ${ }^{41}$ Once returned to Libya, the migrants faced torture and depravation in Libyan internment camps. The director of the Misrata camp admitted, "There is overcrowding, people sleep in corridors. The food, living conditions and accommodation are bad, bad, bad." 42

The European Commission (EUCOM) understood these issues well before the LNCG capacity building programme commenced. In December 2016, the European Union and the International Organization for Migration $(\mathrm{IOM}))$ launched a $€ 346$ million joint initiative designed to protect "migrants along migration routes, providing them with socio-medical care, and offering safer and better governed migration processes". ${ }^{43}$ EUNAVFOR MED also included more human rights training for the LNCG and worked with various law enforcement authorities to weed out bad actors. Finally, the EU Border Assistance Mission Libya (EUBAM Libya), through advising and mentoring activities, worked to improve the human rights record of the Libyan border police and customs service. ${ }^{44}$

By July 2018, EUNAVFOR MED had trained 231 LNCG with 100 more personnel in the pipeline. A new Italian national mission, Mare Sicuro, trained additional members of the Libyan police coastguard. Together, these coastguards were interdicting close to $75 \%$ of all migrants departing from Libya and returning them to Libya-taking tremendous migration pressure off Italy and Malta and allowing Sophia units to focus mainly on non-SAR missions.

Since its inception in 2015, Sophia had evolved from an operation mainly engaged in saving lives at sea to a multifaceted maritime security operation. In addition to building LNCG capacity and fighting human trafficking, the operation eventually enforced both the UN arms and oil embargoes for Libya. The oil embargo mission, added in July 2017, was seen as particularly vital due to its linkages with human trafficking and other crimes. ${ }^{45}$ Finally, Sophia cast a security and maritime domain aware-

41 Hans Witthöft interview.

42 No Escape from Hell, 38.

43 European Commission, EU-IOM Joint Initiative for Migrant Protection and Reintegration.

44 EU Integrated Border Assistance Mission in Libya (EUBAM Libya), March 2019.

45 EEAS, Strategic Review, 27 July 2018, 6-7. 
ness umbrella over a large swath of the Central Mediterranean-which was highly beneficial to both member states concerned about terrorism and also NATO's Operation Sea Guardian. Cooperation between EUNAVFOR MED and NATO reached a new high in 2018 with both parties coordinating operational units in the Mediterranean and sharing information as well as logistical support, including refuelling. ${ }^{46}$

Despite these successes, in the end Sophia could not avoid falling prey to member state politics. On 18 July 2018, the Minister of Foreign Affairs of Italy, Enzo Moavero Milanesi, sent the High Representative of the EU, Federica Mogherini, a letter requesting an immediate revision of migrant disembarkation procedures for Operation Sophia, "indicating that pending that revision Italy would no longer be in a position to accept exclusive disembarkation of persons rescued at sea by the assets of the operation in Italian ports" ${ }^{47}$ Italy's new stance on disembarkation, Goussott explained, put Sophia "between a rock and a hard place" because no other member state stepped up to offer the operation alternative disembarkation ports. Hence, the EC had no choice but to withdraw surface naval assets from the operation. On 31 March 2019, it extended the operation's mandate until 30 September 2019 but it temporarily suspended its naval assets. ${ }^{48}$ On 30 September 2019, it withdrew all surface naval assets from Sophia, effectively ending the naval mission. ${ }^{49}$ A force of six maritime patrol aircraft continued to surveil the Sophia AOR, and the LNCG capacity building mission continued while the EC contemplated the fate of the overall operation. ${ }^{50}$

\section{New Operations: Irini and Themis}

On 19 January 2020, responding to pleas from the UN and Germany, the EC agreed to launch a new operation in the Mediterranean aimed at enforcing the UN arms and oil embargoes through surveillance and, when

46 ibid, 22.

47 EEAS, Strategic Review, 26 July 2018, 30.

48 European Parliament, Legislative Train Schedule: Towards a New Policy on Migration, European Naval Force, Mediterranean Operation Sophia, https:/www.eu roparl.europa.eu/legislative-train/theme-towards-a-new-policy-on-migration/file-e unavfor-med-operation-sophia, accessed 18 May 2020.

49 European Union External Action, EU CSDP Missions \& Operations for Human Security, May 2019.

50 ibid. 
necessary, by conducting inspections in international waters. The "new" mission, called Irini, would also train and build the capacity of the Libyan sea services and contribute to disrupting human trafficking mainly through aerial surveillance. Irini commenced operations on 17 February 2020 - the same date Sophia permanently ceased all activities. Sophia was launched in 2015 as part of an EU response to a surge of illegal immigration in the Central Mediterranean. As much as Sophia evolved over the course of four years, she could not shake off her association with this issue - especially saving lives at sea. The new Irini mission focused on embargo enforcement and put maritime security, conflict resolution and enforcement of international law front and centre.

Triton, which had also seen its interception numbers shrink from 38,000 people in 2015 to just 8,000 in 2017 , was also rebranded. The mission that replaced it in 2018, called Themis, left "the decision on disembarkation to the country coordinating the rescue". Themis would place more emphasis on border control and surveillance than humanitarian rescue. Frontex also shrank Themis's AOR to just 24 miles from the coast of Italy versus $30-138$ miles for Triton-a factor that also reduced the number of SARs. ${ }^{51}$ Frontex, much more so than EUNAVFOR MED, has succeeded in navigating migration politics by being acutely sensitive to the concerns of front-line nations like Italy and making appropriate (and legal) course corrections as requested. Consequently, it is seen more as an ally in the migration effort than an independent actor. In November 2019, the EC approved the expansion of the European Border and Coast Guard Agency standing force from 1,300 to $10,000.52$

\section{Conclusions}

One of the strengths of the EC is its willingness to take a long view of history and recognise that deep structural problems take years and often decades to solve. EU warships still sail in the waters of the Horn of Africa over 12 years after the launch of Atalanta; and EU troops still maintain

51 Steve Schere, "In new EU sea mission, ships not obliged to bring migrants to Italy,” Reuters, 1 February 2018, https://www.reuters.com/article/us-europe-migra nts-italy/in-new-eu-sea-mission-ships-not-obliged-to-bring-migrants-to-italy-idUSK BN1FL62M, accessed 20 May 2020.

52 "EU Expands its Border Force With 10,000-Member Standing Corps," The Maritime Executive, 15 June 2020, https:/www.maritime-executive.com/article/eu-expa nds-its-border-force-with-10-000-member-standing-corps, accessed 20 June 2020. 
peace in the Balkans 16 years after assuming these duties from the NATO SFOR. The Irini and Themis operations must endure in the same spirit, and the EC must stay the course. Incrementally, the council must also work even harder to improve the plight of the migrant, in Libya or wherever he or she may end up. Europe spends more on foreign aid than any country on planet earth. A total of $40 \%$ of official global humanitarian assistance and over half of official global development assistance comes from EUCOM and EU member states..$^{53}$ Its soft power is preeminent among nations, as is its commitment to fundamental human rights. CSDP missions must forge better links with the humanitarian organisations delivering food and other services to refugees and migrants in Libya as well as strengthen its EUBAM mission on the ground in Libya, the Sahel and other African nations.

At sea, better coordination with sea rescue NGOs might further lighten the Frontex and EUNAVFOR roles in migrant rescue and improve the human rights record of the Libyan coastguards. In this regard, continued NGO participation in EUNAVFOR hosted Shared Awareness and De-confliction in the Mediterranean (SHADE MED) conferences is a step in the right direction. Strategic messaging operations should be better coordinated with Frontex, and other partners. In the end, EUNAVFOR's central message should focus on the three concerns originally outlined by Goussot: humanitarianism (saving lives), protecting Europe's borders (ensuring orderly migration), and maritime domain awareness and security (i.e. counter organised crime/terrorism). Information operations also should stress that without Irini and Themis, there will be increased migration, organised crime and deaths at sea.

Finally, the most controversial element of the programme (the LNCG capacity building mission) must not only continue but be expanded to include the Libyan Police Coast Guard because of the dramatic success these agencies have demonstrated in curbing migration and rescuing migrants at sea. Building nascent security organisations takes years of effort and might require more support from European naval and coastguard academies in training Libyan officers. EU funds may be required to augment the meagre salaries of these officers and improve their infrastructure (boats, port facilities, etc.). These coastguards represent the linchpin for the success of the mission going forward, and no effort should be spared to improve not only their effectiveness, but their human rights record as well.

53 Derek E. Mix, The European Union: Foreign and Security Policy, Congressional Research Service Report 7-5700, 8 April 2013, 19. 
In broader terms, EU migration operations feed into allied low-end maritime strategy in a variety of very significant ways. The recently published "European Union Maritime Security Strategy" stakeholder's guide authored by the EC reveals just how closely these operations fit into the goals and principles of the greater strategy. Sophia/Irini/Triton/Themis improve border control and security; counter a variety of security threats; and for the most part adhere to core EU principles (such as multilateralism and respect for the rule of law). ${ }^{54}$ Through these operations, EU navies are further enhancing the union's ability to operate outside the NATO sphere, thereby increasing EU naval capability and interoperability. The experience EU navies gain by working with coastguards, and other law enforcement bodies, not only promotes information-sharing across sectors but forges strategic partnerships that could be critical in a hybrid warfare situation in the Baltic or elsewhere. Lastly, these operations promote the common defence principles espoused in the Lisbon Treaty, build solidarity between member states, and serve to further the process of integration and unification of EU security structures. The migrant crisis has already spurred the creation of an EU European Border and Coast Guard Agency standing force of 10,000 personnel. Conceivably, the positive effects of Sophia/Irini/Triton/Themis could lead to additional standing EU forces. Dr Sebastian Bruns has already floated the idea of a Standing EU Naval Auxiliary (ships utilised heavily in Sophia). ${ }^{55}$ Despite their low-end nature, naval migration operations show no signs of abating. EU navies must leverage these operations to the greatest extent possible in order to improve themselves, justify their existence and project naval power into the Mediterranean and beyond.

54 For more, see the EC, "EU Maritime Security Strategy: Responding Together: A Guide for Stakeholders," https://ec.europa.eu/maritimeaffairs/sites/maritimeaffairs /files/leaflet-european-union-maritime-security-strategy_en.pdf, accessed 26 September 2020.

55 Moritz Brake and Sebastian Bruns, "Towards a Standing European Union Auxiliary Navy,” Europa, Friedrich Ebert Stiftung, https//fes-europe.eu, accessed 27 September 2020. 


\section{Works cited}

Bathke, Benjamin. "When Helping Hurts - Libya's Controversial Coast Guard, Europe's Go-to Partner to Stem Migration.” InfoMigrants, 2019/07/24, https://www. infomigrants.net/en/post/18196/when-helping-hurts-libya-s-controversial-coast-g uard-europe-s-go-to-partner-to-stem-migration, accessed 22 April 2020.

Council Decision (CFSP) 2016/993 of 20 June 2016 amending Decision (CFSP) $2015 / 778$ on a European Union military operation in the Southern Central Mediterranean (EUNAVFOR MED operation SOPHIA). 21 June 2016.

Council of the European Union. "EUNAVFOR MED Operation Sophia: mandate extended until 31 December 2018.” Press Release. 25 July 2017.

Council of the European Union. European Union Maritime Security Strategy (EUMS). 24 June 2014.

Cusumano, Eugenio. “Migrant Rescue as Organized Hypocrisy: EU Maritime Missions Offshore Libya between Humanitarians and Border Control." Sage Journals, 6 June 2018, https://journals.sagepub.com/doi/full/10.1177/0010836718780 175, accessed 20 May 2010.

European Commission. EU-IOM Joint Initiative for Migrant Protection and Reintegration, https://ec.europa.eu/trustfundforafrica/all-news-and-stories/eu-iom-joi nt-initiative-migrant-protection-and-reintegration-new-web-portal_en, accessed 24 April 2020.

EU Maritime Security Strategy: Responding Together: A Guide for Stakeholders. https:/ec.europa.eu/maritimeaffairs/sites/maritimeaffairs/files/leaflet-european-u nion-maritime-security-strategy_en.pdf, accessed 26 September 2020.

European External Action Service (EEAS). EU CSDP Missions \& Operations for Human Security, May 2019.

EU Integrated Border Assistance Mission in Libya (EUBAM Libya), March 2019.

EU Operations in the Mediterranean Sea Fact Sheet. 4 October 2016.

EUNAVFOR MED - Operation Sophia, Six Monthly Report: June $22^{\text {nd }}$ to December $31^{\text {st }}, 2015.29$ January 2016.

EUNAVFOR MED Op Sophia Six Monthly Report, 1 January-31 October 2016. 30 November 2016.

European Union Common Security and Defence Policy: Missions and Operations, Annual Report. 2017.

Strategic Review On EUNAVFOR Med Op Sophia, EUBAM Libya \& EU Liaison And Planning Cell. 26 July 2018.

Strategic Review on EUNAVFOR MED Op Sophia, EUBAM Libya \& EU Liaison and Planning Cell, 27 July 2018.

European Parliament. Legislative Train Schedule: Towards a New Policy on Migration, European Naval Force, Mediterranean Operation Sophia, https://www.eur oparl.europa.eu/legislative-train/theme-towards-a-new-policy-on-migration/file-e unavfor-med-operation-sophia, accessed 18 May 2020. 
European Union Political and Security Committee. Political and Security Committee Decision (CFSP) 2016/118 of 20 January 2016 concerning the implementation by EUNAVFOR MED operation SOPHIA of United Nations Security Council Resolution 2240 (2015) (EUNAVFOR MED operation SOPHIA/ 1/2016). 29 January 2016.

Ewence, Martin. "ANALYSIS - Enduring response: EU NAVFOR and the Mediterranean migration crisis,” Jane's Navy International, 18 November 2015.

Frontex. Annual Activity Report (AAR) 2014. 13 May 2015.

- AAR 2016. 21 June 2017.

- General Report. 2014.

- Risk Analysis for 2019.

Garelli, Glenda et al. "Shifting Bordering and Rescuing Practices in the Central Mediterranean Sea, October 2013-October 2015.” Antipode, vol. 50, No. 3 2018, 813-821.

Human Rights Watch. No Escape from Hell: EU Policies Contribute to Abuse of Migrants in Libya (New York: Human Rights Watch, January 2019).

High Representative of the Union for Foreign Affairs and Security Policy, European Commission. Second report on the implementation of the EU Maritime Security Strategy Action Plan. 14 June 201.

House of Lords, European Union Committee. "Operation Sophia, the EU's naval mission in the Mediterranean: an impossible challenge." $14^{\text {th }}$ Report of Session 2015-16. 13 May 2016.

International Organization for Migration (IOM). Global Migration Trends 2015 Factsheet. 19 April 2016, https://www.iom.int/news/iom-releases-global-migratio n-trends-2015-factsheet, accessed 16 April 2020.

Mentzelopoulou, Maria Margarita and Katrien Luyten, European Parliamentary Research Service, European Parliament. Hotspots at EU External Borders State of Play. PE 623.563. June 2018.

Mix, Derek E. The European Union: Foreign and Security Policy. Congressional Research Service Report 7-5700. 8 April 2013.

Mogherini, Federica. "Congratulations to the EU Military Staff on your $15^{\text {th }}$ Anniversary - 2001 / 2016.” IMPETUS: Magazine Of The EU Military Staff, European External Action Service (EEAS), Brussels, Spring/Summer 2016, Issue \#21, 2-4.

Oberti, Charlotte. "Agreement between Italy and the Libyan coastguard renewed for three years." InfoMigrants, 2020/02/07, https://www.infomigrants.net/en/post /22578/agreement-between-italy-and-the-libyan-coastguard-renewed-for-three-yea rs, accessed 22 April 2020.

Official Journal of the European Communities. Charter of Fundamental Rights Of The European Union. 18 December 2000.

Official Journal of the European Union. COUNCIL DECISION (CFSP) 2015/778 of 18 May 2015 on a European Union military operation in the Southern Central Mediterranean (EUNAVFOR MED). 19 May 2015. 
Poggioli, Sylvia. "Italy Undertakes Lonely, Expensive Mission to Aid Migrants at Sea.” NPR, 24 August 2014, https://www.npr.org/sections/parallels/2014/08/12/3 39881610/italy-undertakes-lonely-expensive-mission-to-aid-migrants-at-sea, accessed 7 April 2020.

Schere, Steve. "In new EU sea mission, ships not obliged to bring migrants to Italy.” Reuters, 1 February 2018, https://www.reuters.com/article/us-europe-migr ants-italy/in-new-eu-sea-mission-ships-not-obliged-to-bring-migrants-to-italy-idU SKBN1FL62M, accessed 20 May 2020.

The Maritime Executive. "EU Expands its Border Force With 10,000-Member Standing Corps.” The Maritime Executive, 15 June 2020, https://www.maritime-e xecutive.com/article/eu-expands-its-border-force-with-10-000-member-standing-c orps, accessed 20 June 2020.

UNHCR. "So Close yet So Far from Safety: Refugees and Migrants Risking Their Lives at Sea to Reach Europe.” 2014, https:/www.unhcr.org/protection/migratio n/542c07e39/close-far-safety-2.html, accessed 9 February 2021.

Zichi, Gian Lorenzo. "European Fleet to address the Migration Challenge in the Mediterranean? The EUNAVFOR MED/Sophia between Lights and Shadows." Athens Journal of Mediterranean Studies, Volume 4, Issue 2, 137-156.

\section{Author Interviews}

De Cock, CDR Philippe, Belgian Navy. 17 October 2018.

Goussot, Christophe, EEAS. 20 June 2019.

Schotte, CDR Sr. Grade Guy, Belgium Navy. 25 September 2019.

Witthöft, Hans, Sea-Eye. Interview with John Sherwood and Kira Frankenthal, Institute for Security Policy at Kiel University. 27 February 2019. 
